\title{
THE IMPACT OF BODY MASS INDEX ON DISEASE PROGRESSION IN ANKYLOSING SPONDYLITIS
}

\author{
Jūlija Zepa 1,2,3,\#, Inita Buliṇa ${ }^{1,2,3}$, Vladimirs Lavrentjevs ${ }^{1}$, Ilze Vīnkalna ${ }^{1,3}$, \\ Liene N̦ikitina-Zaķe ${ }^{4}$, Daina Andersone ${ }^{1,3}$, and Aivars Lejnieks ${ }^{2,5}$ \\ ${ }^{1}$ Center of Rheumatology, Pauls Stradiṇš Clinical University Hospital, 13 Pilsoṇu Str., Rĩga, LV-1002, LATVIA \\ ${ }^{2}$ Rīga Stradinš̌ University, 16 Dzirciema Str., Rīga, LV-1007, LATVIA \\ ${ }^{3}$ Faculty of Medicine, University of Latvia, 19 Raina Blvd., Rīga, LV-1586, LATVIA \\ ${ }^{4}$ Biomedical Research and Study Centre of Latvia, 1 Rātsupītes Str., Rīga, LV-1067, LATVIA \\ ${ }^{5}$ Rīga East Clinical University Hospital, 2 Hipokrāta Str., Rīga, LV-1038, LATVIA \\ \# Corresponding author, julija.zepa@ inbox.Iv
}

Contributed by Aivars Lejnieks

\begin{abstract}
Obesity can be a factor that affects the course of chronic systemic inflammatory arthritis. The objective of this study was to characterise patients with ankylosing spondylitis (AS) according to an evaluation of their body mass index (BMI) and by exploring the link between the overweightness and obesity with routinely measured disease-specific variables, including disease activity (Bath Ankylosing Spondylitis Disease Activity Index BASDAl; Ankylosing Spondylitis Disease Activity Score, using CRP, ASDAScrp), spinal mobility (Bath Ankylosing Spondylitis Metrology Index, $B A S M I)$, functional capacity (BASFI), extraspinal manifestations like fatigue, uveitis, and peripheral arthritis present during the course of the disease. A total of 107 patients were included in the cross-sectional study fulfilling the modified New York criteria for AS. Patients were divided into three groups: with the evaluation of $B M I \leq 24.9,25.0-29.9$ (overweight) and $\geq 30.0$ (obesity). The mean BMI was 25.13 (SD 4.07). 33\% of patients were overweight and $15 \%$ were obese. The mean values of age, duration of AS, ASDAScrp, BASDAl, Bath Ankylosing Spondylitis Functional Index (BASFI), BASMI, pain in spine, and fatigue in the group with $B M I \leq 24.9$ were lower than in the other groups $(\mathrm{p}<0.05)$. There was no difference between groups in age of AS onset, uveitis and peripheral arthritis. AS patients who were overweight or obese had a higher level of the disease activity, pain, fatigue, functional disability and spinal mobility impairment with worse values in the case of obesity.
\end{abstract}

Key words: ankylosing spondylitis, body mass index, disease activity, functional disability, obesity, overweight.

\section{INTRODUCTION}

Ankylosing spondylitis (AS) is a potentially disabling form of systemic chronic inflammatory arthritis with a prevalence from $0.02 \%$ in Sub-Saharan Africa to $0.35 \%$ in Northern Arctic communities (Stolwijk et al., 2016). For example, based on the nationwide, population-based study performed in 2009, the prevalence of clinically diagnosed AS in Sweden was $0.18 \%$ (Exarchou et al., 2015). This disease usually affects young male and female patients in their most productive years (Rudwaleit et al., 2009). The main features of AS are spinal inflammation and structural damage. However, many patients have concomitant extraspinal manifestations classified as peripheral disease, such as arthritis, enthesitis and dactylitis, and/or extraarticular manifestations, such as uveitis, psoriasis and inflammatory bowel disease (IBD). Previous studies dated from 2004 till 2016 reported
$18-58 \%$ prevalence of arthritis, 34-74\% prevalence of enthesitis and $6-8 \%$ prevalence of dactylitis (reported at any time during the disease course). The reported prevalence of uveitis occurring at some point in time during the course of AS varied from $22-37 \%$, and the prevalence of IBD was estimated at $4-16 \%$ and the prevalence of psoriasis at $4-9 \%$ (de Winter et al., 2016). Therefore, the course of the disease can be very different, including low disease activity without extraspinal manifestations and AS with late life-threatening complications. How can we favourably modify the course of the disease? There are many extraspinal modifiable factors usually analysed in different studies evaluating their influence on the course of chronic inflammatory arthritis, for example, body mass index (BMI), smoking, D vitamin etc.

According to the BMI trend analysis to date, global obesity numbers have increased dramatically, from 105 million 
adults in 1975 to 641 million in 2014. However, these statistics do not always include the population that is overweight. When the incidence of being overweight was included within obesity statistics, rates of excess weight have been shown to be dramatically greater. Indeed, the WHO reported that, as a group, the obese and overweight adult population is now approaching $40 \%$ of the world's population, with rates in the US now at $\sim 66 \%$ (Maffetone et al., 2017). The excess of adipose tissue in overweight and obese individuals (routinely expressed by BMI) may have immunodulating properties affecting the course of the disease (Gremese et al., 2014). An increase in adipose tissue, which is considered a dynamic endocrine organ, is associated with increased production of several proinflammatory cytokines (Vargas et al., 2016). To date no longitudinal study or case-control study has investigated the effect of BMI on the risk of AS development. However, analysis of some AS clinical trial data, particularly AS population characteristics, showed that BMI in AS patients is significantly higher in comparison to the healthy population (Zhang and Ding, 2016).

Taking into account the increasing number of obese patients, worldwide investigation of the consequence of excess fat and of fat mass on the course of AS is relevant. The role of fat tissue has not been widely investigated in AS, although some trial data is available evaluating the influence of BMI to the response to TNF $\alpha$ inhibitors such as infliximab (Ottaviani et al., 2012) and adalimumab (Rosas et al., 2016). The data from these studies suggest that overweightness and obesity are associated with a lower rate of success in achieving response status in AS patients. These arguments prompted us to conduct a study evaluating the role of $\mathrm{BMI}$ in the course of the AS, combined with routinely used measurements.

The objective of this study was to characterise patients with AS according to an evaluation of their BMI, exploring the link between the overweightness and obesity with routinely measured disease-specific variables, including disease activity, spinal mobility, functional capacity, extraspinal manifestations of the disease as fatigue, uveitis and peripheral arthritis present during the course of the disease.

\section{MATERIALS AND METHODS}

Patients. One hundred and seven patients were included in the cross-sectional study fulfilling the modified New York criteria for AS (van der Linden et al., 1984). The data presented here focus on patients with adult onset predominantly axial disease who were included in the study between October 2011 and February 2016 in the Centre of Rheumatology of Pauls Stradiņš Clinical University Hospital (inpatient and outpatient department). The inclusion criteria were an age $>18$ years during the onset of the symptoms and fulfilling the modified New York criteria for AS. The exclusion criteria were other chronic or autoimmune inflammatory arthritis (for example, rheumatoid arthritis), depression or other psychiatric diseases diagnosed and/or treated by psychiatrists, moderate or severe cardiac, pulmonary, renal and/or hepatic insufficiency, acute or chronic infection, CNS disorders recorded in medical reports, drug and/or alcohol abuse. Ethical approval was obtained for this study from the local ethics committee at Pauls Stradiňš Clinical University Hospital. Written informed consent was obtained from all the patients in accordance with the principles of the Declaration of Helsinki.

Patients were classified according to their BMI into three groups: normal weight $\leq 24.9 \mathrm{~kg} / \mathrm{m}^{2}$, overweight $25.0-29.9 \mathrm{~kg} / \mathrm{m}^{2}$, obesity was considered with BMI $\geq 30$ $\mathrm{kg} / \mathrm{m}^{2}$ (Anonymous, 2016). C-reactive protein (CRP) levels were collected, and elevated CRP was considered if $\geq 5$ $\mathrm{mg} / \mathrm{L}$. Disease activity was measured by the Bath Ankylosing Spondylitis Disease Activity Index (BASDAI) (Garrett et al., 1994) and by the Ankylosing Spondylitis Disease Activity Score (ASDAS) (using CRP) (Machado et al., 2011). BASDAI consists of 6 patient-reported outcomes, and has an overall score from 0 to 10 ; evaluation 4 represents inactive disease. ASDAS was calculated using the specific formula, including evaluation of back pain (the second item of BASDAI), duration of morning stiffness (the sixth item of BASDAI), patient global, peripheral pain/swelling (the third item of BASDAI) and CRP.

The following variables were chosen for overall characteristics: age, duration of the disease, age of AS onset, duration of morning stiffness (the sixth item of BASDAI; in minutes), functional (BASFI; 0-10) (Calin et al., 1995), metrological (BASMI 3-point answer scale) (Jenkinson et al., 1994) indices, evaluation of enthesitis (the fourth item of BASDAI; 0-10), and uveitis and peripheral arthritis ever during the course of the disease documented in medical reports. Pain of the spine due to AS in the last week on average was evaluated using a NRS 0-10 (0-10: 0 - none; 10 - very severe) as well as patients' global well-being (0-10: 0 - no effect of the disease; 10 - very severe impact). Fatigue was evaluated using the first item from BASDAI questionnaire: "How would you describe the overall level of fatigue/tiredness you have?" The answer was recorded using a 0-10 numerical rating scale (NRS) (0 none and 10 - very severe).

Statistical analysis. Statistical analyses were performed using SPSS v.17.0. Results from categorical and dichotomous variables were expressed as frequencies and continuous variables as means and SDs. $\chi^{2}$ tests were performed for the comparison of categorical data, and the Kruskal-Wallis test for the comparison of continuous variables, as appropriate. $P$ values less than 0.05 were considered significant.

\section{RESULTS}

The mean BMI was 25.13 (SD 4.07). In the study population of 106 AS patients, 33\% were overweight and 15\% were obese (one of the 107 AS patients lacked data for BMI calculation). 
Demographic and clinical data of the 107 (85\% males) evaluated AS patients as well as data from the subgroups enrolled in the study are summarised in Table 1.

The mean values of age, disease duration, CRP, ASDAScrp, BASDAI, BASFI, BASMI in group 1 (BMI $\leq 24.9)$ were lower than the parameters in the groups of patients who were overweight (group 2) and obese (group 3). The evaluation of fatigue and pain in spine was worse in groups 2 and 3. These differences were statistically significant between the groups. There was no statistically significant difference between the groups on age of AS onset, global well-being, enthesitis evaluation and duration of morning stiffness.

$55.1 \%$ of all patients had peripheral arthritis throughout the course of the disease. $35.5 \%$ of all patients had uveitis reported at any time during the course of the disease. There was no statistically significant difference between the groups in presence of peripheral arthritis $(p=0.769)$ or uveitis ( $p=0.614$ ) during the course of the disease (Table 2).

\section{DISCUSSION}

The study confirmed the significant prevalence of overweightness and obesity in patients with AS. Similar results were obtained, for example, from the Groningen Leewarden Axial SpA cohort analysis - of 461 patients with axial SpA, $37 \%$ were overweight and $22 \%$ were obese (Maas et al., 2016).

How can we characterise the AS patient who is overweight or obese? Based on our study, the typical patient is 42 years old and has suffered from disease manifestation for 15 years with high disease activity (supported also by elevated CRP level in blood), a high level of spine pain, significantly expressed functional disability and restrictions on spinal mobility accompanied by a marked expression of fatigue. Furthermore, AS patients with obesity have higher disease activity (ASDAScrp $(p=0.0060)$, BASDAI $(p=0.0088)$ ), functional $(p=0.0002)$ and spinal mobility $(p=0.0010)$ impairment levels, fatigue $(p=0.0007)$ and pain in spine $(p=$ $0.0119)$ evaluation scores than AS patients who are overweight.

Are there any differences in comparison with an AS patient with normal BMI? The answer is "yes". Based on the obtained data, in cases with normal BMI, patients had the following profile: 36 years old patients suffering from disease expression for 10 years with lower (on average moderate) disease activity with some functional disability and restrictions on spinal mobility accompanied by a lower evaluation

Table 1 CHARACTERISTICS OF ANKYLOSING SPONDYLITIS PATIENTS (mean, SD)

\begin{tabular}{|c|c|c|c|c|c|}
\hline Variables & $\begin{array}{l}\text { Whole } \\
(\mathrm{n}=107)\end{array}$ & $\begin{array}{c}\text { BMI } \leq 24.9 \\
\text { Group } 1 \\
(n=55)\end{array}$ & $\begin{array}{c}\text { BMI 25.0-29.9 } \\
\text { Group } 2 \\
(\mathrm{n}=35)\end{array}$ & $\begin{array}{l}\text { BMI } \geq 30 \\
\text { Group } 3 \\
(n=16) \\
\end{array}$ & $p^{\mathrm{a}}$ \\
\hline Age (years) & $38.83(9.69)$ & $36.2(10.2)$ & $41.06(8.49)$ & $43.5(7.87)$ & 0.0106 \\
\hline Disease duration (years) & $12.63(8.02)$ & $10.38(7.79)$ & $13.86(7.67)$ & $18.31(6.23)$ & 0.0008 \\
\hline Age of the onset of AS (years) & $26.12(7.02)$ & $25.81(6.79)$ & $27.31(7.61)$ & $24.38(6.58)$ & 0.3269 \\
\hline BASDAI (0-10) & $4.44(2.25)$ & $3.77(2.03)$ & $4.96(2.43)$ & $5.46(1.97)$ & 0.0088 \\
\hline ASDAScrp & $2.79(1.32)$ & $2.39(1.32)$ & $3.12(1.29)$ & $3.39(0.99)$ & 0.0060 \\
\hline CRP (mg/L) & $12.8(18.08)$ & $11.72(21.61)$ & $13.86(13.93)$ & $14.19(13.36)$ & 0.0104 \\
\hline BASFI (0-10) & $3.41(2.68)$ & $2.53(2.43)$ & $3.91(2.56)$ & $5.49(2.41)$ & 0.0002 \\
\hline BASMI (0-10) & $3.45(2.63)$ & $2.76(2.5)$ & $3.74(2.64)$ & $5.31(2.12)$ & 0.0010 \\
\hline Duration of morning stiffness (minutes) & $51.03(40.3)$ & $45.55(36.13)$ & $56.43(48.2)$ & $57.5(35.82)$ & 0.4528 \\
\hline Evaluation of enthesitis (0-10) & $3.73(3.21)$ & $3.07(3.02)$ & $4.46(3.08)$ & $4.5(3.83)$ & 0.0692 \\
\hline Global well-being (0-10) & $4.88(2.28)$ & $4.42(2.36)$ & $5.14(2.09)$ & $5.88(2.16)$ & 0.0561 \\
\hline Fatigue $(0-10)$ & $4.96(2.64)$ & $4.18(2.52)$ & $5.23(2.79)$ & $6.88(1.36)$ & 0.0007 \\
\hline
\end{tabular}

$\overline{p^{a} \text { value according }}$ to Kruskal-Wallis test

DISTRIBUTION OF PERIPHERAL ARTHRITIS AND UVEITIS IN GROUPS ACCORDING TO BMI (NUMBER OF PATIENTS)

\begin{tabular}{|c|c|c|c|c|c|}
\hline \multirow[b]{2}{*}{$\begin{array}{c}\text { Extraspinal } \\
\text { manifestations }\end{array}$} & \multicolumn{3}{|c|}{ BMI } & \multirow[b]{2}{*}{$\begin{array}{c}\text { Total } \\
\mathrm{n}=106\end{array}$} & \\
\hline & $\begin{array}{c}\text { BMI } \leq 24.9 \\
\text { Group } 1 \\
n=55\end{array}$ & $\begin{array}{c}\text { BMI 25.0-29.9 } \\
\text { Group } 2 \\
\mathrm{n}=35\end{array}$ & $\begin{array}{c}\mathrm{BMI} \geq 30.0 \\
\text { Group } 3 \\
\mathrm{n}=16\end{array}$ & & \\
\hline Peripheral arthritis & $\begin{array}{c}29 \\
49.15 \%\end{array}$ & $\begin{array}{c}20 \\
33.90 \%\end{array}$ & $\begin{array}{c}10 \\
16.95 \%\end{array}$ & $\begin{array}{c}59 \\
100.00 \%\end{array}$ & $p=0.769$ \\
\hline Uveitis & $\begin{array}{c}21 \\
55.26 \%\end{array}$ & $\begin{array}{c}13 \\
34.21 \%\end{array}$ & $\begin{array}{c}4 \\
10.53 \%\end{array}$ & $\begin{array}{c}38 \\
100.00 \%\end{array}$ & $p=0.614$ \\
\hline
\end{tabular}


of spine pain and fatigue in comparison with the groups with overweightness and obesity. The differences between the groups in peripheral arthritis $(p=0.769)$ and uveitis $(p=$ 0.614 ) during the course of the disease, age of AS onset ( $p$ $=0.3269)$, duration of morning stiffness $(p=0.4528)$, expression of enthesitis $(p=0.0692)$ and global wellbeing ( $p$ $=0.0561)$ were not statistically significant.

The data clearly showed that patients who were overweight or obese had higher disease activity (ASDAScrp ( $p=$ $0.0060)$, BASDAI $(p=0.0088)$ ) with more expressed functional and spinal mobility impairment evaluated accordingly as BASFI $(p=0.0002)$ and BASMI $(p=0.0010)$. Thus, BMI can be used as an objective indirect evaluation of the severity of systemic inflammation and/or the consequence of it expressed by functional disability and spinal mobility impairment. Reversible spinal inflammation causes irreversible structural damage leading to spinal mobility impairment and functional disability (Sieper et al., 2008). Interestingly, data obtained from the Korean College of Rheumatology BIOlogics registry revealed that increased BMI is significantly associated with the presence of syndesmophyte, but not with disease activity in axial spondyloarthritis (SpA) (Kim et al., 2017). Based on data from the SPACE cohort on possible impact of BMI to the ASDAS in axial SpA - ASDAS is not affected by BMI in axial SpA patients. The results from SPACE cohort showed that correlations between BMI and CRP or patient-reported outcomes (included in ASDAS) were generally weak (Vargas et al., 2016). In contrast, other authors concluded that BMI is associated with the level of disease activity and functional ability (Durcan et al., 2012; Maas et al., 2016). Additionally, based on data (Durcan et al., 2012) from a cohort of 46 AS patients, $67.5 \%$ were overweight or obese they had a greater burden of symptoms, worse perceptions regarding the benefits of exercise, and enhanced awareness of their barriers to exercising, which raised particular concern for the disease as exercise plays a crucial role. Thus, the recommendation for AS patients to decrease the BMI to the appropriate level is relevant for achievement of remission.

One of the most frequently reported symptoms by patients with axial $\mathrm{SpA}$ is disease-related fatigue (Dernis-Labous et al., 2003). It is a significant component of chronic inflammatory disease defined as dysfunctional, long-lasting and persisting condition, despite adequate periods of rest and sleep (Davies et al., 2013). In our study, fatigue was evaluated by using NRS thus showing the intensity without a description of the duration, time of expression during the day, nor differentiation of physical and psychological input in the evaluation of fatigue. The mean evaluation of fatigue in our patients was high enough, with higher evaluation in the group with obesity ( $p=0.0007)$, thus emphasizing the impact of extraspinal manifestations to the course of the disease. In contrast, not all studies showed a link between fatigue and BMI. For example, in a previous study (Alkan et al., 2015) on the Multidimensional Assessment of Fatigue (MAF) for patients with AS, a correlation with BMI was not observed. There was a statistically significant dif- ference between the groups on back pain evaluation ( $p=$ $0.0119)$ - patients with overweight and obesity had higher scores for back pain level. Thus, an approach to reduce the negative impact of the disease and on the quality of life should be focused on, as well as to reduce the high BMI.

Our data on peripheral arthritis and uveitis is consistent with the published data of meta-analysis on extraspinal manifestations in AS (de Winter et al., 2016): 18-58\% prevalence of arthritis and 22-37\% of uveitis (all reported at any time during the disease). To our knowledge this is the first study ever reported that analysed the link between BMI and uveitis or peripheral arthritis in the course of AS. The impact of the presence of uveitis during the course of AS still remains a challenge. There is data showing that a history of iritis is independently associated with a worse radiological outcome in AS (Doran et al., 2003). Previous results (Heuft-Dorenbosch et al., 2004) showed that AS patients with peripheral arthritis had higher BASDAI than AS patients without extraspinal articular manifestation. This can be explained by two factors: higher evaluation of the BASDAI question on peripheral pain as well as higher values answering other questions regarding fatigue, morning stiffness, spinal pain, and enthesopathy. Thus, peripheral manisfestations contribute to higher disease activity, possibly due to a more extensive inflammation. Interestingly, data from the observation study of the Korean Spondyloarthropathy Registry concluded that the presence of peripheral arthritis delays spinal radiographic progression in AS (Kim et al., 2014). Thus, the clinical and radiological impact of peripheral arthritis as well as the link between inflammation and structural damage in patients with axial SpA, particularly AS, still remains a challenge. Our study showed no reliable impact of the history of uveitis and peripheral arthritis on BMI expression (accordingly, $p=0.614$ and $p=0.769$ ). Therefore, it can be considered that extraspinal manifestations such as uveitis and peripheral arthritis are more connected with other cytokine pathways than overweight/obesity.

\section{CONCLUSION}

AS patients who were overweight and obese had a higher level of disease activity, pain level, fatigue score, functional disability and spinal mobility impairment with higher values in the case of obesity. The results of this study suggest that the BMI can be used as one of the indirect objective clinical signs, which shows the expression of systemic inflammation and induced impairment of mobility in the course of the disease independent on the age of AS onset and predict the response to the treatment.

The authors have declared no conflict of interest.

\section{ACKNOWLEDGMENTS}

We thank Irena Rogovska for guiding the statistical analysis and reading a version of the manuscript and providing feedback. 
We also thank the following rheumatologists for the inclusion of their patients: Evita Sikora, Sarmìte Ābelìte, Janis Arājs, and Ineta Balcune.

\section{REFERENCES}

Alkan, B. M., Fidan, F., Erten, S., Aksekili, H., Alemdar, A., Eroglu, E., Ardicoglu, O., Tosun, A. (2013). Fatigue and correlation with disease-specific variables, spinal mobility measures, and health-related quality of life in ankylosing spondylitis. Mod. Rheumatol., 23 (6), 1101-1107.

Calin, A., Jones, S. D., Garrett, S. L., Kennedy, L. G. (1995). Bath Ankylosing Spondylitis Functional Index. Brit. J. Rheumatol., 34, 793-794.

Davies, H., Brophy, S., Dennis, M., Cooksey, R., Irvine, E., Siebert, S. (2013). Patient perspectives of managing fatigue in Ankylosing Spondylitis, and views on potential interventions: A qualitative study. BMC Musculoskel. Disord., 14, 163.

Dernis-Labous, E., Messow, M., Dougados, M. (2003). Assessment of fatigue in the management of patients with ankylosing spondylitis. Rheumatology, 42, 1523-1528.

de Winter, J. J., van Mens, L. J., van der Heijde, D., Landewe, R., Baeten, D. L. (2016). Prevalence of peripheral and extra-articular disease in ankylosing spondylitis versus non-radiographic axial spondyloarthritis: A meta-analysis. Arthritis Res. Ther., 18, 196.

Doran, M. F., Brophy, S., MacKay, K., Taylor, G., Calin, A. (2003). Predictors of long-term outcome in ankylosing spondylitis. J. Rheumatol., 30, 316-320.

Durcan, L., Wilson, F., Conway, R., Cunnane, G., O’Shea, F.D. (2012). Increase body mass index in ankylosing spondylitis is associated with greater burden of symptoms and poor perceptions of the benefits of exercise. $J$. Rheumatol., 39 (12), 2310-2314.

Exarchou, S., Lindstrom, U., Askling, J., Eriksson, J. K., Forsblad-d'Elia, H., Neovius, M., Turesson, C., Kristensen, L. E., Jacobsson, L. T. H. (2015). The prevalence of clinically diagnosed ankylosing spondylitis and its clinical manifestations: A nationwide register study. Arthritis Res. Ther., 17, 118.

Garrett, S., Jenkinson, T., Kennedy, L. G., Whitelock, H., Gaisford, P., Calin, A. (1994). A new approach to defining disease status in ankylosing spondylitis: The Bath Ankylosing Spondylitis Disease Activity Index. J. Rheumatol., 21, 2286-2291.

Gremese, E., Bernardi, S., Bonazza, S., Nowik, M., Peluso, G., Massara, A., Tolusso, B., Messuti, L., Miceli, M., C., Zoli, A., Trotta, F., Govoni, M., Ferraccioli, G. (2014). Body weight, gender and response to TNF-a blockers in axial spondyloarthritis. Rheumatology, 53, 875-881.

Heuft-Dorenbosch, L., van Tubergen, A., Spoorenberg, A., Landewe, R., Dougados, M., Mielants, H., van der Tempel, H., van der Heijde, D. (2004). The influence of peripheral arthritis on disease activity in ankylosing spondylitis patients as measured with the Bath Ankylosing Spondylitis Disease Activity Index. Arthritis Rheum., 51, 154-159.

Jenkinson, T. R., Mallorie, P. A., Whitelock, H. C., Kennedy, L. G., Garrett, S. L., Calin, A. (1994). Defining spinal mobility in ankylosing spondylitis (AS). The Bath AS Metrology Index. J. Rheumatol., 21, 1694-1698.
Kim, S. K., Choe, J. Y., Lee, S. S., Shin, K. (2017). Body mass index is related with the presence of syndesmophyte in axial spondyloarthritis: Data from the Korean College of Rheumatology BIOlogics (KOBIO) registry. Mod. Rheumatol., 13, 1-7.

Kim, T. J., Lee, S., Joo, K. B., Park, D. J., Park, Y. W., Lee, S. S., Kim, T. H. (2014). The presence of peripheral arthritis delays spinal radiographic progression in ankylosing spondylitis: Observation Study of the Korean Spondyloarthropathy Registry. Rheumatology, 53, 1404-1408.

Maas, P., Arends, S., van der Veer, E., Wink, F., Efde, M., Bootsma, H., Brouwer, E., Spoorenberg, A. (2016). Obesity is common in axial spondyloarthritis and is associated with poor clinical outcome. $J$. Rheumatol., 43 (2), 383-387.

Machado, P., Landewé, R., Lie, E., Kvien, T. K., Braun, J., Baker, D., van der Heijde, D. (2011). Ankylosing Spondylitis Disease Activity Score (ASDAS): Defining cut-off values for disease activity states and improvement scores. Ann. Rheum. Dis., 70, 47-53.

Maffetone, P. B., Rivera-Dominguez, I., Laursen, P. B. (2017). Overfat and underfat: new terms and definitions long overdue. Front. Public Health, 4, 279.

Ottaviani, S., Allanore, Y., Tubach, F., Forien, M., Gardette, A., Pasquet, B., Palazzo, E., Meunier, M., Hayem, G., Job-Deslandre, C., Kahan, A., Meyer, O., Dieude, P. (2012). Body mass index influences the response to infliximab in ankylosing spondylits. Arthritis Res.Ther., 14, R115.

Rosas, J., Linares-Tello, F., Senabre-Callego, J. M., Barber-Valles, X., Santos-Soler, G., Salas-Heredia, E., Pons Bas, A., Cano Perez, C., Garcia-Carrasco, M. (2017). Obesity decreases clinical efficacy and levels of adalimumab in patients with ankylosing spondylitis. Clin. Exp. Rheumatol., 35 (1), 145-148.

Rudwaleit, M., Haibel, H., Baraliakos, X., Listing, J., Märker-Hermann, E., Zeidler, H., Braun, J., Sieper, J. (2009). The early disease stage in axial spondyloarthritis: Results from the German Spondyloarthritis Inception Cohort. Arthritis Rheum., 60, 717-727.

Sieper, J., Appel, H., Braun, J., Rudwaleit, M. (2008). Critical Appraisal of Assessment of Structural Damage in Ankylosing Spondylitis. Arthritis Rheum., 58, 649-656.

Stolwijk, C., van Onna, M., Boonen, A., van Tubergen, A. (2016). Global prevalence of spondyloarthritis: A systematic review and meta-regression analysis. Arthritis Care Res., 68 (9), 1320-1331.

van der Linden, S., Valkneburg, H. A., Cats, A. (1984) Evaluation of diagnostic criteria for ankylosing spondylitis. A proposal for modification of the New York criteria. Arthritis Rheum., 27, 361-368.

Vargas, R. R., van den Berg, R., van Lunteren, M., Ez-Zaitouni, Z., Bakker, P. A. C., Dagfinrud, H., Ramonda, R., Landewe, R., Molenaar, E., van Gaalen, F. A., van der Heijde, D. (2016). Does body mass index (BMI) influence the Ankylosing Spondylitis Disease Activity Score in axial spondyloarthritis? Data from the SPACE cohort. RMD Open, 2, e000283.

World Health Organization. Obesity and overweight. Available from: http://www.who.int/mediacentre/factsheets/fs311/en/ (accessed 12 February 2017)

Zhang, X., Ding, W. (2016). Association of genetic variants in pentraxin 3 gene with ankylosing spondylitis. Med. Sci. Monit., 22, 2911-2916. 


\section{ĶERMEN̦A MASAS INDEKSA IETEKME ANKILOZĒJOŠĀ SPONDILĪTA PROGRESIJĀ}

Aptaukošanās ir viens no faktoriem, kas var ietekmēt hroniska, sistēmiska iekaisuma artrīta gaitu. Mūsu pētījuma mērḳis bija raksturot pacientus ar ankilozējošo spondilītu (AS) atkarībā no ķermeņa masas indeksa (ĶMI), izpētot saistību starp virssvaru un aptaukošanos un ikdienā izmantojamiem slimības novērtējuma instrumentiem, ieskaitot slimības aktivitātes (BASDAI, ASDAScrp), mugurkaula kustīguma (BASMI), funkcionālo spēju (BASFI) novērtējuma indeksus, ārpusmuguras izpausmēm kā nespēks, uveìts, perifērs artrīts (jebkad slimības laikā). Šķērsgriezuma pētījumā tika iekḷauti 107 pacienti atbilstoši modificētiem N̦ujorkas AS kritērijiem. Pacienti tika iedalīti trijās grupās atkarībā no KMI: $\leq 24,9,25,0-29,0$ un $\geq 30,0 \mathrm{~kg} / \mathrm{m}^{2}$. Vidējā KMMI vērtība bija 25,13 (SD 4,07). 33\% pacientu bija ar virssvaru un $15 \%$ ar aptaukošanos. Vecuma, slimības ilguma, ASDAScrp, BASDAI, BASFI, BASMI, nespēka novērtējuma vidējās vērtības pacientiem ar normālu ĶMI bija zemākas, salīdzinot ar pārējām grupām $(p<0,05)$. Statistiski ticamas atšķirības starp grupām netika konstatētas, izvērtējot slimības pirmo simptomu parādīšanās vecumu, perifēro artrītu un uveītu (noteiktu jebkad slimības laikā). Saskaņā ar mums pieejamās zinātniskās literatūras datiem mūsu pētījumā pirmo reizi esam izvērtējuši ĶMI saistību ar uveīta un perifēra artrīta sastopamību AS slimības gaitā. AS pacientiem ar virssvaru vai aptaukošanos ir augstāka slimības aktivitāte, sāpju un nespēka novērtējums, funkcionālās nespējas indekss un mugurkaula kustīguma traucējumu pakāpe, turklāt augstāki rezultāti ir grupā pacientiem ar aptaukošanos. 